\title{
CURRENT LITERATURE ON HUMAN MEMORY, LEARNING. AND THINKING
}

\section{HUMAN LEARNING}

HORVITZ, J. M. (L'niv. of Wisconsin, Madison, Wis. 53706), \& LEVIN, J. $\mathrm{R}$. Semantic and imaginal factors in learning as related to age. Journal of Experimental Child Psychology, $1972,14,11-20$.

HUGHES, G. H. (Auburn Univ., Auburn, Ala. 36833), McINTYRE, S., DRAGOIN, W. B., \& NOLAN R. Effect of sensory cueing in learning and retention. Psychological Reports, 1972, 31, 315-318.

LITROWNIK, A. J. (San Diego State Coll., San Diego, Calif. 92115). Observational learning in retarded and normal children as a function of delay between observation and opportunity to perform. Journal of Experimental Child Psychology, $1972,48,117 \cdot 125$.

MARTON, F. K. (Inst. for Ed. Rsch., Goteborg Univ., Göteborg, Sweden), \& SANDQVIST, G. Learning while typing. Quarterly Journal of Experimental Psychology, 1972, 24, 287-290.

SHEEHAN, P. W. (Univ. of New England, Armidale, N.S.W., Australia 2351). Role of imagery in incidental learning: Replication and extension of an effect. Jourital of Experimental Psychology, 1972, 95, $226 \cdot 228$

SHINE, L. C., II (Univ, of Dayton, Dayton, Ohio 45409), WIANT. J., \& DA POLITO, F. Effect of learning on hemispheric dominance and tree recall in a single subject. Psychological Reports, 1972. 31, 227-230.

YARMEY, A. D. (Lniv. of Guelph, Guelph, Ont., Canada). \& BOWEX, $\therefore$. $V$. The role of imagery in incidental learning of educable retarded and normal children. Journal of Experimental Child Psychology, 1972, 14, 303-312.

\section{CONDITIONING}

LAMBERTH, J. (Univ. of Oklahoma, Norman, Okla. 73069 ), GAY, R. A., \& DYCK, D. G. Differential reward magnitude and human conditioning $\mathrm{w}$ ith social reinforcers. Psychonomic Science, 1972, 28, $231-233$

LEVIS. D. J. (Univ. of Iowa, Iowa City. Iowa 52240), \& LEVIN. H.S. Escape maintenance under serial and simultaneous compound presentations of separately established conditioned stimuli. Journal of Experimental Psychology, 1972, 95,451-452.
LOCKHART, R. A. (Dir, Psychophysiol. Rsch. Lab., Ctr, for the Study of Behav. Disorders, Camarillo State Hosp.. Camarillo, Calif. 93010). Interrelations between amplitude. latency, rise time, and the Edelberg recovery measure of the galvanic skin response. Psychophysiology, 1972, 9, 437-442.

LOMBARDO, J. P. (State Univ. of New York, Curtiand, N.Y. 13045). TATOR, G. D., \& WEISS, R. F. Performance changes in human conditioning as a function of shifts in the magnitude of attitudinal reinforcement. Psychonomic Science, 1972, 28, 215-218.

MINKE, K. A. (Univ. of Hawaii, Honolulu, Hawaii 96822). Operant conditioning of a grammatical form class with second-grade children. Journal of Genetic Psychology, $1972,121,21-30$.

POETTER, R. A., \& LEWIS, P. (Ohio Univ.. Athens, Ohio 45701). Facilitation of human operant responding by stimuli which precede aversive events. Journal of Experimental Psychology, 1972, 95, 382.337

TELLER, K. J., DIETER, R., \& SUBOSKI, M. D. Time estimation and the interstimulus interval function in classical conditioning. Journal of Experimental Psychology, 1972, 95, 145-448

WEISS, R. F, (L'niv. of Oklahoma, Norman, Okla. 73069), BECK, C. M., \& STICH, M. H. Correlated delay of reinforcement in the instrumental conditioning of conversational behavior. Psychonomic Science, 1972, 28, 211-212

WERDEN, D., \& ROSS, L. E. (Lniv. of Wisconsin, Madison, Wis. 53706). A comparison of the trace and delay classical conditioning performance of normal children. Journal of Experimental Child Psychology. 1972, 14, 126-132.

\section{DISCRIMINATION}

CAI.EF, R. S. (West Virginia Wesleyan Coll., Buckhannon, W. Va. 26201), CALEF, R. A. B., BONE, R. N., \& BLTTERMORE, G. A human analogue of discrimination contrast: $S-$ contrast as a function of magnitude of S+. Psychonomic Science, 1972, 29, 118-119.

ELIAS, M. F. (West Virginia Univ., Morgantown, W. Va. 26506), \&
KINSBOLRNE, M. Time course of identity and category matching by spatial orientation. Journal of Experimental Psychology, 1972, 95, $177-183$

GHOLSON. B. (Hunter Coll of CUNY, New York, N.Y. 10021), LEVINE, M., \& PHILIIPS, S. Hypotheses, strategies, and stereotypes in discrimination learning. Journal of Experimental Child Psychology, 1972, 13. $423-446$

GOLLIN, E. S. (Liniv. of Colorado. Boulder, Colo. 80302 ). \& SCHADLER, M. Relational learning and transfer by young children. Journal of Experimental Child Psychology, 1972, 14, 219-232

ROWE. E. J. (Mem. Univ. of Newfoundland, St. John's, Nfld., Canada). Discrimination learning of pictures and words: A replication of picture superiority. Journal of Experimental Child Psychology, $1972,14,323-328$.

SPIKER, C. C. (Univ. of Iowa, Iowa City, Iowa 52240). CROLL, W. L., \& MILLER, A. A. The effects of verbal pretraining on the multidimensional generalization behavior of children. Journal of Experimental Child Psychology, $1972,13,558.572$.

TIGHE, T. J. (Dartmouth Coll.. Hanover. N.H. 03755). \& TIGHE, L. S. Reversals prior to solution of concept identification in children. Journal of Experimental Child Psychology. 1972, 13, 488-501

Discrimination Shift

DICKERSON, D. J. (Lniv. of Connecticut. Storrs, Conn 06268). NOVIK, N., \& GOLLD. S. A. Acquisition and extinction rates as determinants of age changes in discrimination shift behavior. Journal of Experimental Psychology, 1972, 95, 116.122.

KENDLER. H. H. (Lniv. of California, Santa Barbara, Calif. 93106), KENDLER, T $S$. \& WARD.J.W. An ontogenetic analysis of optional i n t rad imensional and extradimensional shifts. Journal of Experimental Psychology, 1972, 95, 102-109

KENDLER, H. H. (Univ. of California, Santa Barbara. Calif. 93106). \& WARD, J. W. Reversal learning: The effects of conceptual and perceptual training in the absence of differential observing responses. Psychonomic Science, 1972, 28. 346-348.

SMILEY, S. S. (Western Washington 
State Coll., Bellingham, Wash. 98225 ). Optional shift behavior as a function of dimensional preference and relative cue similarity. Journal of Experimental Child Psychology, $1972,14,313-322$.

\section{VERBAL LEARNING}

AMIDON, A. (Devel. Psychol. Program, City Univ. Grad. Ctr., New York, N.Y. 10036), \& CAREY, P. Why five-year-olds cannot understand before and after. Journal of Verbal Learning \& Verbal Behavior, 1972, 11 , 417-423.

BAIRD, R. (Wright State Univ., Dayton, Ohio 45431). On the role of chance in imitation-comprehension-production test results. Journal of Verbal Learning \& Verbal Behavior, 1972, 11, 474-477

DELPRATO, D. J. (Eastern Michigan Univ., Ypsilanti, Mich. 48197). Pair-specific effects in retroactive inhibition. Journal of Verbal Learning \& Verbal Behavior, 1972 , $11,566-572$.

GRONINGER, L. D. (Univ. of Maryland, Baltimore Co., Baltimore, Md. 21228), BELL, B., CYMER, W. \& WESS, B., JR. Storage aspects of nouns presented under imagery and acoustic coding instructions. Journal of Experimental Psychology, 1972, 95, 195-201.

GRUNEBERG, M. M. (Univ, Coll, of Swansea, Sch. of Soc. Studies, Singleton Park, Swansea, Wales). The serial position curve and the distinction between short- and long-term memory. Acta Psychologica, 1972, 36, 221-225.

KENDLER, H. H. (Univ. of California, Santa Barbara, Calif. 93106), \& WARD, J. W. Recognition and recall of related and unrelated words. Psychonomic Science, 1972, 28, $193 \cdot 195$

KULHAVY, R. W. (Arizona State Univ., Tempe, Ariz. 85281). Effects of embedding orienting stimuli in a prose passage. Psychonomic Science, 1972, 28, 213.214.

MARSHALL, P. H. (Texas Tech Univ., Lubbock, Tex. 79409), \& WERDER, P. R. The effects of the elimination of rehearsal on primacy and recency. Journal of Verbal Learning \& Verbal Behavior, 1972, $11,649 \cdot 653$

RUNQUIST, W. N. (Univ. of Alberta, Edmonton, Alta., Canada), \& EVANS, A. Stimulus recognition and associative coding. Journal of Experimental Psychology, 1972, 95. $242 \cdot 244$

SILVESTRI, P. J. (Herbert H. Lehman Coll. of CUNY, New York, N.Y. $10000), \&$ GAVURIN, E. I. Anagram solving and relative solution-word transition probability. Perceptual \& Motor Skills, 1972, 35, 338 .

THURLOW, M. L. (Univ. of Minnesota, Minneapolis, Minn. $55455)$ \& TURNURE, J. E. Elaboration structure and list length effects on verbal elaboration phenomena. Journal of Experimental Child Psychology, 1972, 14, 184-195.

WEIS'T, R. M. (Univ. of Nebraska-Lincoln, Lincoln, Nebr. $68508)$. The role of rehearsal: Recopy or reconstruct. Journal of Verbal Learning \& Verbal Behavior, $1972,11,440-450$.

Paired-Associate Learning

AIKEN, E. G. (Nav. Pers. \& Trng. Rsch. Lab., San Diego, Calif. 92133). Paired-associate recall as a function of mnemonic instructions, trials, and intention to learn. Psychological Reports, 1972, 31, 295-299.

BARTON, A. K. (Univ. of Texas, Austin, Tex. 78712), \& YOUNG, R. K. Transfer from free-recall to paired-associate learning. Journal of Experimental Psychology, 1972, 95, $240-241$

BERRY, F. M. (Columbus Coll., Columbus, Ga. 31907), JOUBERT, C. E., \& BAUMEISTER, A. A. Stjmulus selection and meaningfulness at different stages of paired-associate learning. Journal of Experimental Psychology, 1972, 95, 189-194.

CHAMPION, R. A. (Univ. of Sydney, Sydney, N.S.W. 2006, Australia), McCANN, T. E., \& RUFFELS, J. A. Frustration phenomena in paired-associate learning. Journal of Experimental Psychology, 1972, 95 , $123-134$

COFFMAN, D. (Univ. of Missouri, Columbia, Mo. 65201), \& McALEER, C. Paired-associate learning using color responses varying in form. Perceptual \& Motor Skills, 1972, 35, 281-282.

DOBBS, A. R. (Univ. of Alberta, Edmonton, Alta., Canada), \& KEELING, J.M. The effect of presenting repaired verbal or pictorial mediator prompts on chaining. Psychonomic Science, $1972,28,196-198$.

GIURINTANO, S. L. (Univ. of San Diego, Alcala Park, San Diego, Calif. 92110 ). Directionality of associations in paired-associate learning. Journal of Experimental Psychology, 1972, 95, 463-464.

GORDON, D. A. (Univ. of Alabama, University, Ala. 35486), \& BAUMEISTER, A. A. The effects of rehearsal instructions upon the paired-associate leaining of normal and retarded subjects. Journal of
Genetic Psychology, 1972, 121, 31-39.

HALL, J. F. (Pennsylvania State Univ., University Park, Pa. 16802). Associative strength and word frequency as related to stages of paired-associate learning. Canadian Journal of Psychology, 1972, 26. 252-258.

HOLYOAK, $K$. (Univ of British Columbia, Vancouver, B.C., Canada), HOGETERP, H., \& YUILLE, J. C. A developmental comparison of verbal and pictorial mnemonics in paired associate learning. Journal of Experimental Child Psychology, 1972, 14, 53-65.

KIRK, W. J. (Memphis State Univ., Memphis, Tenn. 38152), \& JOHNSON, J. T., JR. Negative transfer as a function of $\mathrm{IQ}$ and mode of presentation in paired-associate learning. Journal of Experimental Child Psychology, $1972,14,233-241$.

OSBORNE, J. W. (Dept. of Ed. Psychol., Univ. of Alberta, Edmonton, 7, Alta., Canada). Interaction of arousal and number of learning trials in paired-associate learning. Journal of Experimental Psychology, 1972, 95, 135.139.

POSTMAN, L. (Univ. of California, Berkeley, Calif. 94720), \& STARK, K. On the measurement of retroactive inhibition in the $A \cdot B$, A.D paradigm by the multiple-choice method: Reply to Merryman. Journal of Verbal Learning \& Verbal Behavior, 1972, $11,465-473$.

SADALLA, E. K. (Univ. of California, Los Angeles, Calif. 90024), \& LOFTNESS, S. Emotional images as mediators in one-trial paired-associate learning. Journal of Experimental Psychology, 1972, 95, 295-298.

SPIT', H. H. (Dir. of Rsch., E. R. Johnstone Trng. \& Rsch. Ctr., Bordentown, N.J. 08505). Effects of redundancy level and presentation method on the paired-associate learning of educable retardates, third graders, and eighth graders. Journal of Experimental Psychology, 1972, 95, 164-170.

WOLFF, P. (Dept. of Ed. Psychol., Univ. of Wisconsin, Madison, Wis. 53706), LEVIN, J. R., \& LONGOBARDI, E. T. Motoric mediation in children's paired-associate learning: Effects of visual and tactual contact. Journal of Experimental Child Psychology, $1972,14,176-183$.

Verbal Discrimination Learning COLE, L. E. (Dept. of Behav. Sci. Arkansas Polytech. Coll., Russellville, Ark. 72801), \& KANAK, N. J. Transfer of implicit 
associative responses between free-recoll learning and verbal discrimination learning tasks. Journal of Experimental Psychology, 1972, 95, 110-115.

ORNSTEIN, P. A. (Princeton Univ., Princeton, N.J. 08540), GRANT, D. A., \& WATTERS, W. C. Semantic genera!ization over a bipolar dimension of meaning. Journal of Experimental Psychology, 1972, 95, $202 \cdot 210$.

ROWE, E. J. (Mem. Univ. of Newfoundland, St. John's, Nfld., Canada). Imagery and frequency processes in verbal discrimination learning. Journal of Experimental Psychology, 1972, 95, 140-146.

ULLRICH, J. R. (Univ. of Montana, Missoula, Mont. 59801), \& BALOGH, B. A. Imagery and meaningfulness of right and wrong items in verbal discrimination learning. Psychonomic Science, $1972,29.68 \cdot 70$.

Word \& Sentence Learning

BACHARACH, V. R. (Bureau of Child Rsch., Univ. of Kansas, Lawrence, Kans. 66044), KELLAS, G., \& McFARLAND, C. E. Structural properties of transitive and intransitive verbs. Journal of Verbal Learning \& Verbal Behavior, 1972, $11,486-490$.

BEGG, I. (McMaster Univ., Hamilton, Ont., Canada). Recall of meaningful phrases. Journal of Verbal Learning \& Verbal Behavior, 1972, 11 . 431-439.

BEGG, I. (McMaster Univ, Hamilton, Ont., Canada), \& ROWE, E. J. Continuous judgments of word frequency and familiarity. Journal of Experimental Psychology, 1972, $95,48-54$

BOWER, G. H. (Stanford Lniv., Stanford, Calif. 94305), \& REITMAN, J. S. Mnemonic elaboration in multilist learning. Journal of Verbal Learning \& Verbal Behavior, 1972, 11 , 478-485.

EHRI, L. C. (Dept. of Ed., Univ. of California, Davis, Calif. 95616). Sentence contexts as facilitators of noun pair learning in children. Journal of Experimental Child Psychology, 1972, 14, 242-256.

GLANZER. M. (New York Univ., New York, N.Y. 10003), KOPPENAAL, L., \& NELSON, R. Effects of relations between words on short-term storage and long-term storage. Journal of Verbal Learning \& Verbal Behavior, 1972, 11 . 403-416.

YARMEY, A. D. (Univ. of Guelph, Guelph, Ont., Canada), \& SAYER, L. A. Associative learning of abstract and concrete nouns and their subject-drawn pictorial representations. Canadian Journal of Psychology, 1972, 26, 240-251.

\section{REINFORCEMENT}

ALLEN, G. A. (Miami Univ., Oxford, Ohio 45056). Memory probes during two-choice, differential reward problems. Journal of Experimenta! Psycho!ogy, 1972, 95, 78-89.

BERLYNE, D. E. (Univ. of Toronto, Toronto 181 , Ont., Canada). Reinforcement values of visual patterns compared through concurrent performances. Journal of the Experimental Analysis of Behavior, 1972, 18, 281-285.

DUBANOSKI, R. A. (Univ. of Hawaii, Honolulu, Hawaii 96822). An empirical test of Mowrer's theory of imitation. Psychonomic Science, $1972,28,203-204$.

FUREDY, J. J. (Univ. of Toronto, Toronto, Ont., Canada), \& BIEDERMAN, G. B. Development of the reinforcing effect of signaling modifiable shock. Perceptual \& Motor Skills, 1972, 35, 31-34.

GREENBAUM, C. W. (Dept. of Psychol.. Hebrew Univ. of Jerusalem, Jerusalem, Israel), WEISS, L. R., \& LANDAU, R. Type of reward, social class, and concept-switching in preschool children. Journal of Genetic Psychology, 1972, 121, 91-106.

KAPLAN, K. J. (75A Bristol Ave., Toronto 170 , Ont., Canada). Vicarious reinforcement and model's behavior in verbal learning and imitation. Journal of Experimental $\mathbf{p}_{\text {sychology }}$ 1972, 95, $4.48-450$.

LAMBERTH, J. (Univ. of Oklahoma, Norman, Okla. 73069), GAY, R. A., \& DYCK, D. G. Differential reward magnitude and human conditioning with socia! reinforcers. Psychonomic Science, 1972, 28, $231 \cdot 233$.

LIU, I.-M. (Natl. Taiwan Univ., Taipei, Taiwan, Republic of China). Effects of "right" and "wrong" in a Thorndikian experiment. Journal of Experimental Psychology, 1972, 95, 365-369.

REDD, W. H. (Eunice Kennedy Shriver Ctr., Box C, Waverley, Mass. 02179 ). Attention span and generalization of task-related stimulus control: Effects of reinforcement contingencies. Journal of Experimental Child Psychology, 1972, 13, 527-539.

WEISS, R. F. (Univ. of Oklahoma, Norman, Okla. 73069), BECK, C. M., \& STICH, M. H. Correlated delay of reinforcement in the instrumental conditioning of conversational behavior. Psychonomic Science, 1972, 28, $211 \cdot 212$.

WII.LIAMS, B. R. (Univ. of Illinois, Champaign, Hl. 61820). Effects of verbal reinforcement combination on children's responses to blank trials. Journal of Experimental Child Psychology, 1972, 14, 50-42.

\section{HUMAN MEMORY}

ALLEN, G. A. (Miami Univ., Oxford, Ohio 45056). Memory probes during two-choice, differential reward problems. Journal of Experimental Psychology, 1972, 95, 78-89.

EPSTEIN. W. (Univ. of Wisconsin, Madison. Wis. 53206), \& WILDER, L. Searching for to-be-forgotten material in a directed forgetting task. Journal of Experimental Psychology, 1972, 95, 349-357.

FOZARD. J. L. (VA Outpatient Clinic, 17 Court St., Boston. Mass. 02108), \& WEINERT, J. R. Absolute judgments of recency for pictures and nouns after various numbers of intervening items. Journal of Experimental Psychology, 1972, 95,472-474.

GLANZER, M. (New York Univ., New York, N.Y. 10003), KOPPENAAL, L. \& NELSON, R. Effects of relations between words on short-term storage and long-term storage. Journal of Verbal Learning \& Verbal Behavior, 1972, 11, 403-416.

GRONINGER, L. D. (Univ. of
Maryland, Baltimore Co., Baltimore, Md. 21228), BELL, B., CYMER, W., \& WESS, B.. JR. Storage aspects of nouns presented under imagery and acoustic coding instructions. Journal of Experimental Psychology, 1972, 95,195-201.

GRUNEBERG, M. M. (Lniv. Coll. of Swansea, Sch. of Soc. Studies, Singleton Park, Swansea, Wales). The serial position curve and the $d$ istinction between short- and long-term memory. Acta Psychologica, 1972, 36, 221-225

HOLDING, D. H (Univ. of Louisville, Louisville, $\mathrm{Ky}$. 40208). Brief visual memory for English and Arabic letters. Psychonomic Science. 1972. 28. $241-242$

HOLYOAK, K. (Univ. of British Columbia, Vancouver, B.C. Canada). HOGETERP, H., \& YUILLE, J. C. A developmenta! comparison of verbal and pictorial mnemonics in paired-associate learning. Journal of Experimental Child Psychology, 1972, 14, 53-65.

HLGHES, G. H. (Auburn Univ. Auburn, Ala. 36833), McINTYRE, 
S., DRAGOIN, W. B., \& NOLAN, R. Effect of sensory cueing in learning and retention. Psychological Reports, 1972, 31, 315-318.

JONES, E. C. (Frostburg State Coll., Frostburg, Md. 21532), \& DENNIS, M. E. Perceptual closure as a function of gap size. Perceptual \& Motor Skills, 1972, 35, 126.

KENDLER, H. H. (Univ. of California, Santa Barbara, Calif. 93106), \& WARD, J. W. Recognition and recall of related and unrelated words. Psychonomic Science, 1972, 28, 193-195.

KROLL, N. E. A. (Univ. of California, Davis, Calif. 95616), PARKINSON, S. R., \& PARKS, T. E. Sensory and active storage of compound visual and auditory stimuli. Journal of Experimental Psychology, 1972, 95, 32-38.

ROBBINS, D. (Emory Univ., Atlanta, Ga. 30322), \& WISE, P. S. Encoding variability and imagery: Evidence for a spacing-type effect without spacing. Journal of Experimental Psychology, 1972, 95, 229-230

STANNERS, R. F. (Oklahoma State Univ., Stillwater, Okla. 74074), \& HEADLEY, D. B. Pupil size and instructional set in recognition and recall. Psychophysiology, 1972, 9, 505-511.

TELL, P. M. (Florida Tech. Univ., Orlando, Fla. 32816). The role of certain acoustic and semantic facturs at shori and long retertion intervals. Journal of Verbal Learning \& Verbal Behavior, 1972, $11,455-464$

WELLS, J. E. (Univ. of Toronto, Toronto, Ont., Canada). Encoding and memory for verbal and pictorial stimuli. Quarterly Journal of Experimental Psychology, 1972, 24, $242 \cdot 252$.

\section{LONG-TERM MEMORY}

FROST, N. (Princeton Univ., Princeton, N.J. 08510). Encoding and retrieval in visual memory tasks. Journal of Experimental Psychology, 1972, 95, 317-326.

JACOBY, L. L. (Iowa State Univ., Ames, Iowa 50010), \& BARTZ, W. H. Rehearsal and transfer to LTM. Journal of Verbal Learning \& Verbal Behavior, 1972, 11 , 561.565 .

JOHNSON, M. K. (State Univ. of New York, Stony Brook, N.Y. 11790), BRANSFORD, J. D., NYBERG, S. E., \& CLEARY, J, J. Comprehension factors in interpreting memory for abstract and concrete sentences. Journal of Verbal Learning \& Verbal Behavior. 1972, 11, 451-454. KISS, G. R. (MRC Speech \&
Communication Unit, Univ. of
Edinburg, Edinburgh, Scotland). Long-term memory: A state-space approach. British Journal of Psychology, 1972, 63, 327-341.

NELSON, T. O. (Univ. of Washington, Seattle, Wash. 98195), \& SMITH, E. E. Acquisition and forgetting of hierarchically organized information in long-term memory. Journal of Experimental Psychology, 1972, 95, 388-396

SMITH, E. E. (Stanford Univ., Stanford, Calif. 94305 ), HAVILAND, S. E., BUCKLEY, P. B., \& SACK, M. Retrieval of artificial facts from long-term memory. Journal of Verbal Learning \& Verbal Behavior, 1972, 11, 583-593.

TZENG, O. J. L. (Pennsylvania State Univ., University Park, Pa. 16802). A triggering system for scanning processes in long-term memory. Journal of Verbal Learning \& Verbal Behavior, 1972, 11 , $662 \cdot 670$.

\section{Recognition Memory}

BROWN, A. L. (Children's Rsch. Ctr., Univ. of Illinois, Champaign, III. 61820), \& CAMPIONE, J. C. Recognition memory for perceptually similar pictures in preschool children. Journal of Experimental Psychology, 1972, 95, 55-62.

HALL, J. W. (Sch. of Ed., Northwestern Univ., Evanston, Ill. 60201). Experimentally acquired associations in memory encoding by preschoolers. Psychonomic Science, $1972,29,113-114$

HOPKINS, R. H. (Washington State Univ., Pullman, Wash. 99163), \& EDWARDS, R. E. Pronunciation effects in recognition memory. Journal of Verbal Learning \& Verbal Behavior, 1972, 11, 534-537.

KIRSNER, K. (Univ, of Toronto, Toronto 5, Ont., Canada). Naming latency facilitation: An analysis of the encoding component in recognition reaction time. Journal of Experimental Psychology, 1972, 95, 171-176.

KRISTOFFERSON, M. W. (Psychiat. Dept., McMaster Univ., Hamilton, Ont., Canada). When item recognition and visual search functions are similar. Perception \& Psychophysics, 1972, 12, 379-384. McCORMACK, P. D. (Carleton Univ., Ottawa, Ont., Canada, K1S 5B6), \& SWENSON, A. I. Recognition memory for common and rare words. Journal of Experimental Psychology, 1972, 95, 72-77.

SCHU'LZ, L. S. (Coll. of Ed., Univ. of Delaware, Newark, Del. 19711), \& STRAUB, R. B. Effects of high-priority events on recognition or adjacent items. Journal of Experimental Psychology, 1972, 95. 467-469.

THOMSON, D. M. (Monash Univ. Clayton, Victoria 3168 , Australia). Context effects in recognition memory. Journal of Verbal Learning \& Verbal Behavior, 1972, $11,497-511$.

WICKER, F. W. (Dept. of Ed. Psychol., Univ. of Texas, Austin, Tex. 78712), \& HOLLEY, F. M. Recognition ratings and imagery mediation with pictures and words. Psychonomic Science, 1972, 29, 120-122.

Recall

AIKEN, E. G. (Nav. Pers. \& Trrg. Rsch. Lab., San Diego, Calif. 92133). Paired-associate recall as a function of mnemonic instructions, trials, and intention to learn. Psychological Reports, 1972, 31, 295-299.

ANDERSON, J. R., \& BOWER, G. H. (Stanford Univ., Stanford, Calif. 94305). Configural properties in sentence memory. Journal of Verbal Learning \& Verbal Behavior, 1972, $11,594-605$.

BEGG, I. (McMaster Univ., Hamilton, Ont., Canada). Recall of meaningful phrases. Journal of Verbal Learning \& Verbal Behavior, 1972, 11 , 431-439.

BREITENSTEIN, D. L. (Eastern State Hosp., Williamsburg, Va. 23185) Rehearsal and modality effects on delayed recall of continuously presented paired associates. Psychonomic Science, 1972, 28, 355-356.

del CASTILLO, D. M. (Univ. of Toledo, Toledo, Ohio 43606), \& GUMENIK, W. E. Sequential memory for familiar and unfamiliar forms. Journal of Experimental Psychology, 1972, 95, 90-96.

DELPRATO, D. J. (Eastern Michigan Univ., Ypsilanti, Mich. 48197). Pair-specific effects in retroactive inhibition. Journal of Verbal Learning \& Verbal Behavior, 1972, $11,566-572$.

EBERT, T. H., \& FALLON, D. (State Univ. of New York, Binghamton, N.Y. 13901). Recall and resistance to unlearning of verbal mediating associates as a function of anticipation interval. Journal of Experimental Psychology, 1972, 95, 251-257.

HUDSON, R. L. (Mississippi State Univ., State College, Miss. 39762), \& DAVIS, J. L. The effects of intralist cues, extralist cues, and category names on categorized recall. Psychonomic Science, 1972, $29,71 \cdot 75$.

HUMPHREYS, M. S. (Univ. of British Columbia, Vancouver 8 , B.C., 
Canada). Recall and repetition in a modified right-wrong paradigm. Journal of Verbal Learning \& Verbal Behavior, 1972,11 , 573-582.

JOHNSTON, W. A. (Univ. of Utah, Salt Lake City, Utah 84112), GRIFFITH, D., \& WAGSTAFF, R. R. Speed, accuracy, and ease of recall. Journal of Verbal Learning \& Verbal Behavior, 1972, 11 , $512-520$.

LANDAUER, T. K., \& MEYER, D. E. (Bell Tel. Labs., Murray Hill, N.J. 07974). Category size and semantic-memory retrieval. Journal of Verbal Learning \& Verbal Behavior, 1972, 11, 539-549.

RUNQUIST, W. N. (Univ of Alberta, Edmonton 7, Alta., Canada). Formal and semantic similarity of stimuli and recall time. Psychonomic Science, 1972, 29, 79-80.

YONGE, G. D. (Dept. of Ed., Univ. of California, Davis, Calif. 95616), \& SASSENRATH, J. M. Set, structure, and the recall of words. Canadian Journal of Psychology, 1972, 26, 268-276.

\section{Free Recall}

BORGES, M. A. (Univ. of California, San Diego, La Jolla, Calif. 92037). Increasing item accessibility in free recall. Journal of Experimental Psychology, 1972, 95, 66-71.

COLLE, H. A. (Univ. of Chicago, Chicago, nl. 60637). The reification of clustering. Journal of Verbal Learning \& Verbal Behavior, 1972 , $11,624-633$.

DOLINSKY, $R$. (Univ. of Toledo, Toledo, Ohio 43606). Clustering and free recall with alternative organizational cues. Journal of Experimental Psychology, 1972, 95. $159-163$

DONG, T. (Bucknell Univ., Lewisburg, $\mathrm{Pa}, 17837$ ). Probe versus free recall. Journal of Verbal Learning \& Verbal Behavior, 1972,11 . $654-661$

FAGAN, J. F., III (Case Western Reserve Univ., Cleveland, Ohio 44106). Rehearsal and free recall in children of superior and average intelligence. Psychonomic Science, $1972,28,352.354$.

GIANUTSOS, R. (Adelphi Univ., Garden City, Long Island, N.Y. 11530). Free recall of grouped words. Journal of Experimental Psychology, 1972, 95, 419-428.

HERRIOT, P. (Hester Adrian Rsch. Ctr., Manchester Univ., Manchester 13, England). The effect of category cues on the free recall of retarded adults. Psychonomic Science, 1972, 28, 341-342.

HUMPHREYS, M. S. (Univ. of British Columbia, Vancouver 8, B.C.,
Canacia), PETRUSIC, W. M., \& SCHWARTZ, R. M. Free recall following a switch in encoding class. Journal of Experimental Psychology, 1972, 95, 455-457.

I,OCASCIO, D., \& LEY, R. (State Univ., of New York, Albany, N.Y. 12203). Associative reaction time, meaningfulness, and mode of study in free recall. Journal of Experimental Psychology, 1972, 95, 460-462

MARSHALL, P. H. (Texas Tech Univ. Lubbock, Tex. 79409), \& WERDER, P. R. The effects of the elimination of rehearsal on primacy and recency. Journal of Verbal Learning \& Verbal Behavior, 1972, $11,649-653$.

PELLEGRINO, J. W. (Inst. for the Study of Intellectual Behav., Univ. of Colorado, Boulder, Colo. 80302), \& BATTIG, W. F. Effects of semantic list structure differences in free recall. Psychonomic Science, $1972,29,65-67$

SHINE, L. C., II (Univ. of Dayton, Dayton, Ohio 45409), WIANT, J., \& DA POLITO, F. Effect of learning on hemispheric dominance and free recall in a single subject. Psychological Reports, 1972, 31, 227-230.

SURWILLO, W. W. (Dept. of Psyciniat, Univ. of Louisvilie, Sch. of Med., Louisville, Ky. 40201), GELBART, H., ARENBERG, D., \& GOLD, P. Incidence and disiribution of ear-orde i iespondirig in free recall of dichotic stimuli. Psychological Reports, 1972, 31, 155-164

WATKINS, M. J. (Birkbeck Coll., Univ. of London, London, England). Locus of the modality effect in free recall. Journal of Verbal Learning \& Verbal Behavior, $1972,11,644-648$.

WEIST, R. M. (Univ. of Nebraska, Lincoln, Nebr. 68508). The role of rehearsal: Recopy or reconstruct. Journal of Verbal Learning \& Verbal Behavior, 1972,11 , $440-450$

\section{SHORT-TERM MEMORY}

BUNT, A. A. (Inst. for Percep. TNO, Soesterberg, The Netherlands), \& SANDERS, A. F. Some effects of cognitive similarity on proactive and retroactive interference in short-term memory. Acta Psychologica, 1972, 36, 190-196.

CONRAD, R. (Nuffield Hearing \& Speech Ctr., 330 Grays Inn Rd., London, W.C.1, England). The developmental role of vocalizing in short-term memory. Journal of Verbal Learning \& Verbal Behavior, $1972,11,521-533$

DETTERMAN, D. K. (Univ. of Dayton, Dayton, Ohio 45409), \&
ELLIS, N. R. Determinants of induced amnesia in short-term memory. Journal of Experimental Psychology, 1972, 95, 308-316.

FALKENBERG, P. R. (Wake Forest Univ., Winston-Salem, N.C. 27109). Recall improves in short-term memory the more recall context resembles learning context. Journal of Experimental Psychology, 1972, $95,39-47$

GORFEIN, D. S. (Div. of Nat. Sci. New Coll., Sarasota, Fla. 33578), \& JACOBSON, D. E. Proactive effects in short-term recognition memory. Journal of Experimental Psychology, 1972, 95, 211-214.

JONES, S. (Univ. Coll. London, London, England). Imagery in a sinort-term memory task. Psychonomic Science, 1972, 29, 76-78.

KAMIL, M. L. (Arizona State Univ., Tempe, Ariz. 85282). Memory for repeated words and parallel structure in compound sentences. Journal of Verbal Learning \& Verbal Behavior, 1972,11 , 634-643.

KANTOWITZ, B. H. (Purdue Univ., Lafayette, Ind. 47907). Interference in short-term motor memory: Interpolated task difficulty, similarity, or activity? Journal of Experimental Psychology, i972, 95, $264 \cdot 274$

MALMI, R. A. (Miami Univ., Oxford, Ohio 45056), \& JAHNKE, J. C. Invariani repetition structure and the Ranschburg effect. Psychonomic Science, 1972, 28, 247-250.

MARSHALL, P. H. (Texas Tech Univ., Lubbock, Tex. 79409). Recognition and recall in short-term motor memory. Journal of Experimental Psychology, 1972, 95, 147-153.

MEUNIER, G. F. (Dept. of Gen. \& Exptl. Psychol., Ball State Univ., Muncie, Ind. 47306), RITZ, D., \& MEUNIER, J. A. Rehearsal of individual items in short-term memory. Journal of Experimental Psychology, 1972, 95, 465-467.

MYER, B. M., \& O'CONNELL, D. C (St. Louis Univ., St. Louis, Mo. 63103). Memory span: Effects of string length and string composition. Journal of Experimental Psychology, 1972, 95, $231 \cdot 233$.

MYER, B. M. (St. Louis Univ. St. Louis, Mo. 63103), \& O'CONNELL, D. C. Memory span: Effects of symbol orientation. Psychonomic Science, 1972, 28, 199-202.

NICKERSON, R. S. (Bolt Beranek \& Newman, Inc., 50 Moulton St., Cambridge, Mass. 02138). Auditory codability and the short-term retention of visual information. Journal of Experimental Psychology, 1972, 95, 429.436. 